\title{
Cadherin-1 and cadherin-3 cooperation determines the aggressiveness of pancreatic ductal adenocarcinoma
}

Carole Siret $^{1,4}$, Aurélie Dobric ${ }^{1,4}$, Anna Martirosyan ${ }^{1}$, Chloé Terciolo ${ }^{1}$, Sébastien Germain ${ }^{1}$, Renaté Bonier ${ }^{1}$, Thassadite Dirami ${ }^{1}$, Nelson Dusetti ${ }^{2}$, Richard Tomasini ${ }^{2}$, Marion Rubis ${ }^{2}$, Stéphane Garcia ${ }^{2,3}$, Juan lovanna ${ }^{2}$, Dominique Lombardo ${ }^{1}$, Véronique Rigot ${ }^{\star, 1}$ and Frédéric André ${ }^{\star, 1}$

${ }^{1}$ Aix-Marseille Université, Inserm UMR 911, CRO2, 27 blvd Jean Moulin, Marseille 13385, France; ${ }^{2}$ Centre de Recherche en Cancérologie de Marseille (CRCM), INSERM U1068, CNRS UMR 7258, Aix-Marseille Université and Institut Paoli-Calmettes, Parc Scientifique et Technologique de Luminy, Marseille 13009, France and ${ }^{3}$ Hôpital Nord, Marseille 13015, France

Background: Pancreatic ductal adenocarcinoma (PDAC) is characterised by an extensive tissue invasion and an early formation of metastasis. Alterations in the expression of cadherins have been reported in PDAC. Yet, how these changes contribute to tumour progression is poorly understood. Here, we investigated the relationship between cadherins expression and PDAC development.

Methods: Cadherins expression was assessed by immunostaining in both human and murine tissue specimens. We have generated pancreatic cancer cell lines expressing both cadherin-1 and cadherin-3 or only one of these cadherins. Functional implications of such genetic alterations were analysed both in vitro and in vivo.

Results: Cadherin-3 is detected early at the plasma membrane during progression of pancreatic intraepithelial neoplasia 1 (PanIN1) to PDAC. Despite tumoural cells turn on cadherin-3, a significant amount of cadherin-1 remains expressed at the cell surface during tumourigenesis. We found that cadherin-3 regulates tumour growth, while cadherin-1 drives type I collagen organisation in the tumour. In vitro assays showed that cadherins differentially participate to PDAC aggressiveness. Cadherin-3 regulates cell migration, whereas cadherin-1 takes part in the invadopodia activity.

Conclusions: Our results show differential, but complementary, roles for cadherins during PDAC carcinogenesis and illustrate how their expression conditions the PDAC aggressiveness.

Pancreatic ductal adenocarcinoma (PDAC), the most frequent form of pancreatic cancer, is the fourth leading cause of cancer deaths (Kleeff et al, 2016). During the last decade there has been an alarming worldwide increase in its incidence rate. The absence of early detection tools combined with ineffective treatments are the main reasons of a poor prognosis of pancreatic cancer. The result of these factors combination is that PDAC is projected to become the leading cause of cancer deaths in western countries by 2030 (Rahib et al, 2014).
Pancreatic ductal adenocarcinoma is indeed one of the most lethal cancers with a 5-year survival rate of less than $5 \%$ (Kleeff et al, 2016). The low survival rates associated with this human malignancy reflect a diagnosis at later stages characterised by a well-developed, dense, desmoplastic stroma, as well as the presence of metastasis in other organs (Karandish and Mallik, 2016). To overcome this devastating disease, it is essential to develop early detection methods including the identification of new molecular targets.

\footnotetext{
*Correspondence: Dr V Rigot; E-mail: veronique.rigot @univ-amu.fr or Dr F Andre; E-mail: frederic.andre@univ-amu.fr

${ }^{4}$ These authors contributed equally to this work.
}

Received 27 July 2017; revised 18 October 2017; accepted 19 October 2017; published online 21 November 2017

(C) 2018 Cancer Research UK. All rights reserved 0007 - 0920/18 
Pancreatic ductal adenocarcinoma is thought to evolve through progression of precursor lesions, called pancreatic intraepithelial neoplasia (PanINs) (Singh and Maitra, 2007). PanINs are classified into a four-tier classification (including PanIN-1A, 1B, -2, -3) reflecting a progressive greater architectural distortion of the ducts, loss of the columnar epithelia's polarity, and nuclear pleomorphism, cumulating in PDAC with the invasion of the basement membrane. Growing evidence from molecular studies indicates that PDAC is genetically very complex with a high diversity of mutations compared with other cancers. However, KRAS (PanIN1), P16/ CDKN2A (PanIN-2), TP53 and MAD4/DPC4 (PanIN-3) are the most commonly altered genes in a stepwise fashion and provide a model for the PDAC development (Hruban et al, 2008). In addition to these commonly recognised genetic drivers of pancreatic carcinogenesis, a recent genomic analysis of PDAC has increased the number of genomic alterations (Waddell et al, 2015; Bailey et al, 2016).

It is well known that tumour progression involves changes in tumour cell capacities to adhere and communicate with neighbouring cells. Among cell-cell adhesion defects, changes in cadherin expression have a critical role in tumour progression and metastasis (Thiery, 2009). Classical cadherins are a family of single-span transmembrane domain glycoproteins that primarily mediate calcium-dependent cell-cell adhesion, which are differentially expressed throughout the body (Nelson, 2008). These glycoproteins establish homophilic adhesion between neighbouring cells through their extracellular cadherin domain and play cohesive organising functions required for tissue integrity (Niessen et al, 2011). The most extensively studied classical cadherins include cadherin-1, -2 and -3, formerly termed E-, N- and P-cadherin (Gul et al, 2017). The intracellular domain of cadherins is associated with the cytoplasmic proteins termed catenins that link cadherins to the cytoskeleton and cell signalling pathways. Therefore, the alterations among cadherins can affect not only cell-cell adhesive properties, but also the signal transduction activity. The later can modulate a large number of cell functions including tumourigenesis. A cadherin subtype-switching-from cadherin-1 to cadherin-2 was reported in PDAC (Al-Aynati et al, 2004; Nakajima et al, 2004). Moreover, it has been suggested that this phenomenon contributes to metastatic dissemination of tumour cells ( $\mathrm{Su}$ et al, 2016).

In humans, cadherin-3 is only detected in a few organs (Imai et al, 2008). However, its overexpression is strongly associated with a poor prognosis in some solid tumours including breast, lung and pancreatic cancers (Taniuchi et al, 2005; Imai et al, 2008; Ribeiro and Paredes, 2014; Sakamoto et al, 2015). In vitro studies have shown that cadherin-3 induces pancreatic tumour cell motility and invasiveness (Taniuchi et al, 2005; Sakamoto et al, 2015), suggesting that blocking cadherin-3 could be a novel therapeutic approach for the treatment of aggressive pancreatic cancer. Although cadherin-3 expression has been reported in PDAC, its expression and role in the early stages of pancreatic carcinogenesis has not been studied (Taniuchi et al, 2005; Imai et al, 2008; Sakamoto et al, 2015). Indeed, the cadherin-3 is not yet considered as an early biomarker of PDAC.

Since a cadherin-1 staining was observed at the cell membrane in $50-70 \%$ of the PDAC cases (Al-Aynati et al, 2004), it was tempting to speculate that pancreatic cancer cells can express at their surface both cadherin-1 and -3 . The aim of this study was therefore to determine whether simultaneous cadherin-1 and -3 expressions could induce a more aggressive biological behaviour in PDAC. To this end, the expression of these two cadherins was immunohistochemically examined through human pancreatic cancer development and in KPC mouse model. Moreover, we have deciphered the role of each cadherin in cell invasiveness both in vitro and in vivo by using orthotopic and ectopic pancreatic tumour mouse models.

\section{MATERIALS AND METHODS}

Cell culture and tissues. BxPC-3 cells were routinely cultured as previously described (Fabre et al, 1993) and authenticated using STR profiling (ATCC). Primary cultures from human tumours (CRCM08 and CRCM110 cells) were cultured in serum-free ductal media as previously published (Gayet et al, 2015). Cells were passaged in the laboratory for no more than 10 passages. Cells were tested for Mycoplasma monthly.

A pancreas adenocarcinoma tissue array (\#PA484; 24 cases) and a pancreas intraepithelial neoplasia, pancreatitis and cancer tissue array (\#BIC14011a; 24 cases) were purchased from Pantomics (Euromedex, Souffelweyersheim, France).The tissue array of 55 PDAC samples from xenografted tumours was obtained either by surgery or endoscopic ultrasound-guided fine-needle aspiration biopsy, as previously described (Duconseil et al, 2015). Some tumour tissue samples were obtained after pancreatic resection (duodeno-pancreatectomy) from patients diagnosed with pancreatic adenocarcinoma (Gastroenterology and Digestive Surgery departments, Timone Hospital, Marseille, France; CRO2 Agreement DC20131857) between February 2007 and February 2016. All specimens were re-evaluated by an expert pathologist.

PanINs, tumour or control pancreatic tissues from $P d x 1$ $C r$,Ink $4 a^{f l / f l}$ LSL-Kras ${ }^{G 12 D}$ mice (Leca et al, 2016) were fixed in $4 \%$ (wt/vol) formaldehyde for immunochemistry.

Gene expression microarrays. Gene expression microarrays from xenografted tumours issued from 55 PDAC tissue samples (see above) were performed as previously described (Duconseil et al, 2015). All array data are available on the Gene Expression Omnibus (http://www-ncbi-nlm-nih-gov.gate2.inist.fr/geo; Accession number GSE55513).

Cadherin invalidation. Cadherin-1 or cadherin-3 was stably knocked down in human pancreatic adenocarcinoma BxPC-3 cell line by RNA interference technique. To do so, mission shRNA lentiviral transduction particles (Sigma, St Quentin Fallavier, France) have been used as previously described for melanoma IGR 39 cell line (Siret et al, 2015). Briefly, two lentiviral transduction particles were chosen per cadherin (TRCN000023 7843 and TRCN0000237840 for cadherin-1 and TRCN0000423836 and TRCN0000235419 cadherin-3) and a negative control (MISSION Non-Mammalian shRNA Control Transduction Particles $\mathrm{SHC002V)}$ was included. Cells were infected with lentiviral transduction particles according to the manufacturer's instructions. Small hairpin RNA-containing cells were selected with $5 \mu \mathrm{g} \mathrm{ml}^{-1}$ puromycin and cloned. Cell surface cadherin extinction was assessed by both immunofluorescence (Figure 3A) and western blot (Supplementary Figure S1).

Spheroid formation assay. Spheroid formation assay was used to investigate the effect of cadherins on the cell-cell adhesion properties as previously described (Terciolo et al, 2017). Isolated cells were seeded onto U-bottom untreated tissue culture 96-well plates at a concentration of 5000 cells per well in $100 \mu \mathrm{l}$ DMEM containing $10 \%$ FCS and $0.24 \%$ methylcellulose. Spheroids were grown for $24 \mathrm{~h}$ and pictures were taken using an Olympus microscope (objective $\times 4$ ). The size of the spheroids was quantified by measuring the area occupied by cells using ImageJ software (rsb.info.nih.gov/ij/).

3D-invasion assay. Cells were cultured for $72 \mathrm{~h}$ as described above to obtain compact spheroids. The latter were embedded into $1.6 \mathrm{mg} \mathrm{ml}^{-1}$ of bovine collagen I matrix (Advanced Biomatrix) diluted in $0.12 \%$ methylcellulose and covered with serum-free medium. Spheroids were then incubated for $24 \mathrm{~h}$ in a temperature and $\mathrm{CO}_{2}$ controlled chamber mounted on an inverted microscope Olympus IX83. Images were captured every $60 \mathrm{~min}$ using an orca- 
flash4 camera (Hamamatsu) with a $\times 4$ objective. The size of the spheroids was quantified by measuring the area occupied by cells using ImageJ software (rsb.info.nih.gov/ij/). In this experiment, cell invasion is independent of cell proliferation since cell treatment with mytomicin $\mathrm{C}$ did not alter the results obtained in 3D invasion (data not shown).

2D-invasion assay. Owing to their inability to form spheroids, the 3D invasion assay was unachievable for CRCM08 cells. In order to study their invasive properties, in vitro invasion through type I collagen was performed using transwell-based cell culture chamber systems (Millipore-Chemicon). Cells were suspended in DMEM/ $0.1 \%$ BSA and added at a concentration of 20000 cells per well to the upper chamber containing a polycarbonate membrane filter of $8 \mu \mathrm{m}$ pore size and a type I collagen layer. The lower chamber was filled with DMEM supplemented with $1 \%$ FCS. Plates were incubated under standard culture conditions for $24 \mathrm{~h}$. Cells remaining on the upper side of the filter and type I collagen were removed using a cotton swab. The invasive cells on the lower side of the filter were stained with the crystal violet. Quantification of invasive cells was performed in two independent experiments performed in triplicate. The invasion index was calculated as the mean number of migrated cells counted in 10 microscopic fields per well.

Wound healing assay. Cell monolayers were wounded using a sterile tooth-pick, washed twice and incubated in serum-free medium. Plates were incubated for $6 \mathrm{~h}$ in a temperature and $\mathrm{CO}_{2}$ controlled chamber mounted on an inverted microscope Olympus IX83. Images were captured every $5 \mathrm{~min}$ using an orca-flash4 camera (Hamamatsu) with a $\times 40$ objective.

Isolated cell trajectory. Isolated cells were seeded on a type I

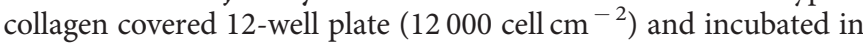
serum-free medium for $6 \mathrm{~h}$ in a temperature and $\mathrm{CO}_{2}$ controlled chamber mounted on an Olympus IX83 inverted microscope. Single cell trajectories were analysed by videomicroscopy by capturing images every 5 min using an orca-flash 4 camera with a $\times 40$ objective. The cell tracks were obtained using ImageJ software. The values for the assessment of migration speed, velocity and directionality were obtained using ImageJ software. Migration speed was determined by the ratio between the total distance and duration of cell migration. Cell velocity corresponds to the distance between the positions of the cells at the beginning and the end of the experiment divided by time. Cell directionality is the ratio between cell velocity and cell speed.

Fluorescent-gelatin degradation assay. Coverslips coated with FITC-conjugated gelatin (Sigma) were prepared as described by (Steffen et al, 2008). Isolated cells were plated on FITC-conjugated gelatin at 70000 cells cm $^{-2}$ for $16 \mathrm{~h}$ and then fixed in $4 \%$ paraformaldehyde. The areas of degraded matrix were observed with an SP5 Leica confocal microscope equipped with LAS AF Lite software. ImageJ software was used to evaluate the number of invadopodia per cell. At least 150 cells from three different coverslips were chosen randomly and analysed.

Subcutaneous and orthotopic xenografts of pancreatic cancer cells. All experimental procedures involving animals were performed in accordance with the French Guidelines and approved by the ethical committee of Marseille (agreement 50-31102012). BxPC-3 cells were harvested by mild trypsinisation, washed twice in PBS, and then suspended in Matrigel at $2 \times 10^{6}$ cells per $100 \mu \mathrm{l}$. To induce tumours, cell suspension was injected subcutaneously (s.c.) into the flank of 6-8-week-old female NMRI-Foxn1nu/ Foxn1nu mice (Charles River Laboratories, L'Arbresle, France; six mice per group). Injected mice were monitored daily and killed 3 weeks after inoculation. Tumours were removed, weighed, and a digital caliper was used to measure their volumes. Tissue specimens were fixed in $4 \%$ formalin, embedded in paraffin and further cut into $4 \mu \mathrm{m}$ sections, immediately stored at $4{ }^{\circ} \mathrm{C}$. The latter were then subjected to Masson's trichrome staining (RAL Diagnostics; Prochilab, Lormont, France) or to immunohistofluorescence (IHC).

Orthotopic xenografts were performed as described elsewhere (Kim et al, 2009; Chai et al, 2013). BxPC-3 cells in single suspension were mixed with Matrigel (BD Biosciences, Le-Pontde-Claye, France) at a ratio of $10^{6}$ cells per $50 \mu \mathrm{l}$ Matrigel. Mice were anaesthetised with 5\% isoflurane in oxygen. An incision $(1-1.5 \mathrm{~cm})$ was created in the left abdominal flank under aseptic conditions. The pancreas was carefully exposed, and $50 \mu \mathrm{l}$ of cell solution diluted in Matrigel was injected into the tail of the pancreas ( $n=4$ per group). The peritoneum and fascia were closed in separate layers using a continuous 4/0 Prolene suture; the skin wound was closed in a similar way. Mice received s.c. injections of analgesic (Buprenorphine $0.1 \mathrm{mg} \mathrm{kg}^{-1}$ ) before the operation and $6 \mathrm{~h}$ following the suturing.

Immunofluorescence. Cells plated on glass coverslips were fixed for $20 \mathrm{~min}$ with $2 \%$ formaldehyde in PBS. Thereafter, cells were permeabilised with $0.1 \%$ saponin in PBS for $20 \mathrm{~min}$, and blocked for $30 \mathrm{~min}$ in PBS containing 4\% (w/v) BSA. Cadherin-1 and cadherin-3 were sequentially detected by incubation with mouse HECD-1 mAb (Takara, Saint-Germain-en Laye, France), and rabbit Ab (2130s, Cell signalling Technology, Saint-Quentin-enYvelines, France), respectively. After three washes, samples were incubated for $1 \mathrm{~h}$ with Alexa Fluor 488- and 594-conjugated goat Ig $\left(20 \mu \mathrm{g} \mathrm{ml}^{-1}\right)$, raised against mouse and rabbit Igs respectively. Samples were then washed and mounted in ProLong Gold (Invitrogen, Illkirch, France). After dewaxing and antigen retrieval, paraffin-embedded $4 \mu \mathrm{m}$ sections of human pancreatic tumour biopsies were treated and subjected to double immunostaining, as described above. Images were captured and analysed using a SP5 Leica confocal microscope equipped with LAS AF Lite software. The intensity and distribution patterns of specific immunofluorescence staining were evaluated by two blinded, independent observers using a semi-quantitative score (graded as $0=$ none, $1=$ weak, $2=$ moderate, $3=$ strong staining, and $4=$ saturated signal). This analysis was performed without any knowledge of anatomopathological evaluation, the diagnosis or the standard performed pathological haematoxylin reaction of each specimen.

Statistical analysis. Data are presented as the means \pm s.d. for three independent experiments performed in triplicate. Comparison between the two conditions was made using the MannWhitney test. $P<0.05$ was considered statistically significant in all analyses and is indicated by '***) when $P<0.001$, '**' when $P<0.01$ and ' ' ' when $P<0.05$.

\section{RESULTS}

Cadherin-3 expression increases during PDAC progression. To date, there is no information available concerning cadherin-3 expression in PDAC precursor lesions. We therefore analysed its expression in both human and murine tissue specimens. In healthy human pancreas, cadherin-3 was located in the cell cytoplasm, whereas cadherin-1 was found at the sites of cell-cell contacts (Figure 1A and Supplementary Figure S2). Moreover, cadherin-3 was progressively observed at the plasma membrane during carcinogenesis from PanIN-1 to PDAC. It should be noted that cadherin-1 remained associated with the cell membrane; although a small decrease in the staining intensity was observed between PanIN-2 and PDAC. We scored the expression level of both cadherin- 1 and cadherin- 3 in all examined tissues. The ratio cadherin-3/cadherin-1 increased from the PanIN-1 to PDAC and was maximal for the grade III of PDAC (Figure 1B). This reflected the concomitant increase of cadherin- 3 expression and the partial 
cadherin-1 extinction during the tumour progression. Our data were confirmed using the PDX1-Cre, Kras ${ }^{\mathrm{G} 12 \mathrm{D}}$, Ink4a/Arf flox/flox mice, a model that develops PDAC from PanIN lesions similar to the human disease (Supplementary Figure S3). In this mouse model, cadherin-1 expression was reduced, while cadherin-3 levels were increased at the cell membrane during progression from PanIN-1 to PDAC.

Taken together these results indicate that cadherin-3 is expressed early during PDAC carcinogenesis, suggesting that this molecule could be an early marker. Despite the appearance of cadherin-3 at the cell membrane, significant amounts of cadherin-1 remained associated with the cell membrane.

Co-localisation of cadherin-3 with cadherin-1 during PDAC progression. Double immunostaining experiments were performed to determine whether both cadherin-1 and cadherin-3 are co-expressed in pancreatic tissues. Dual staining showed that once cadherin-3 is expressed, it localises with cadherin- 1 in the same cells at cell-cell contact sites (Figure 1A). This observation strongly suggests that cadherin subtype switching is not a general feature in PDAC. To confirm this hypothesis, we analysed both cadherin-1 and cadherin-3 mRNA expression in 55 PDAC samples from patients preserved as xenografts in nude mice. Both cadherin1 and cadherin- 3 transcripts were detected at the same time in a large majority of xenografts (Figure 2A). Quantification of the immunostaining of cadherin- 1 and cadherin- 3 in those samples confirmed that there is no switch from cadherin- 1 to cadherin- 3 in PDAC (Figure 2B). It should be noted that cadherin-3 expression level was higher in xenografts issued from metastasis than those obtained from primary tumours (Figure 2C).

Altogether, these results suggest that in PDAC both cadherin-1 and cadherin-3 could elaborate adhesive networks that may regulate tumoural cell behaviour. To decipher the functional effects of cadherin- 1 and cadherin- 3 co-expression, we established cell models where the expression of these cell-cell adhesion molecules can be manipulated. The human pancreatic cancer cell line BxPC-3 was used as a model system. These cells express indeed high levels of both cadherin-1 and cadherin- 3 at cell-cell contacts (Figure 3A). To stably and selectively knockdown the expression of cadherin-1 or cadherin-3, we used shRNA, targeting each one of the two cadherins. We selected among the several clones obtained, one clone with an effective and efficient silencing for cadherin-1 or cadherin-3 (Supplementary Figure S1). The generated stable cell lines were called cadh $-1^{+} / \mathrm{cadh}^{-} 3^{+}$(no cadherin depletion), cadh $-1^{+} /$cadh $^{-} 3^{-}$(cadherin-3 depletion) and cadh- $1^{-} /$cadh- $3^{+}$(cadherin-1 depletion). We also used PDACderived primary cell cultures derived from patient-derived xenograft (PDX) in nude mice (Figure 3B). CRCM110 cells express both cadherin-1 and cadherin-3, whereas CRCM08 cells express only cadherin-3.

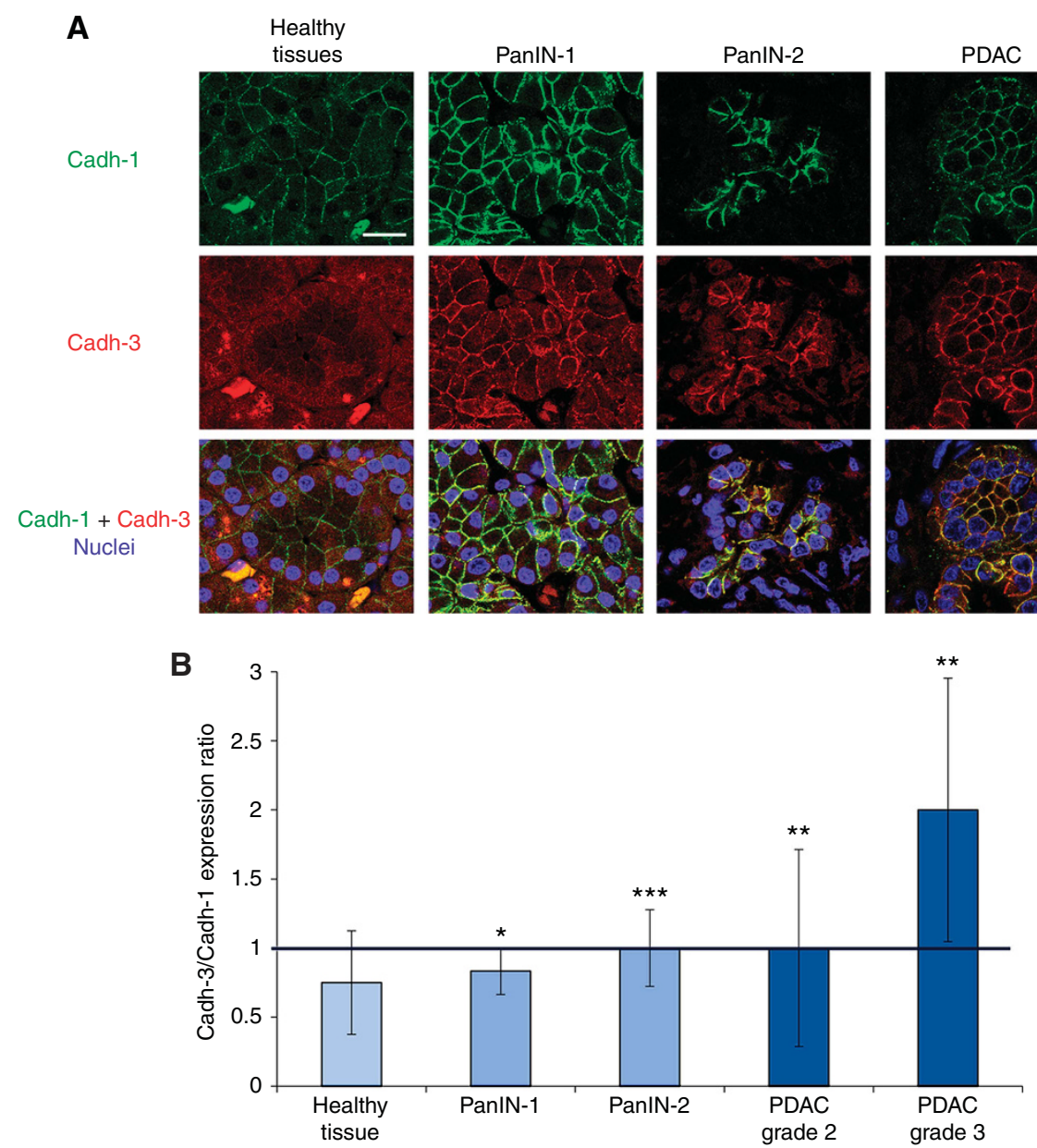

Figure 1. Cadherin-1 and cadherin-3 expression during PDAC progression. (A) Sections of human pancreatic tissue samples were sequentially stained with mouse anti-cadherin-1 and rabbit anti-cadherin-3 Abs. Tissues were then incubated with Alexa 488-conjugated goat anti-mouse and Alexa 594-conjugated Abs and were observed with a confocal microscope. Cell nuclei were stained with Draq5. Scale bar: $25 \mu \mathrm{m}$. (B) Pancreas adenocarcinoma and pancreatic intraepithelial neoplasia (PanIN) tissue microarrays, as well as cancer tissue array were immunostained and observed as described in (A). Cadherin-1 and cadherin-3 staining were scored as described in Materials and Methods. Results are expressed as

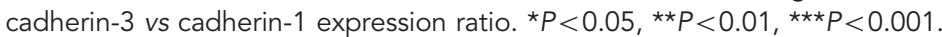



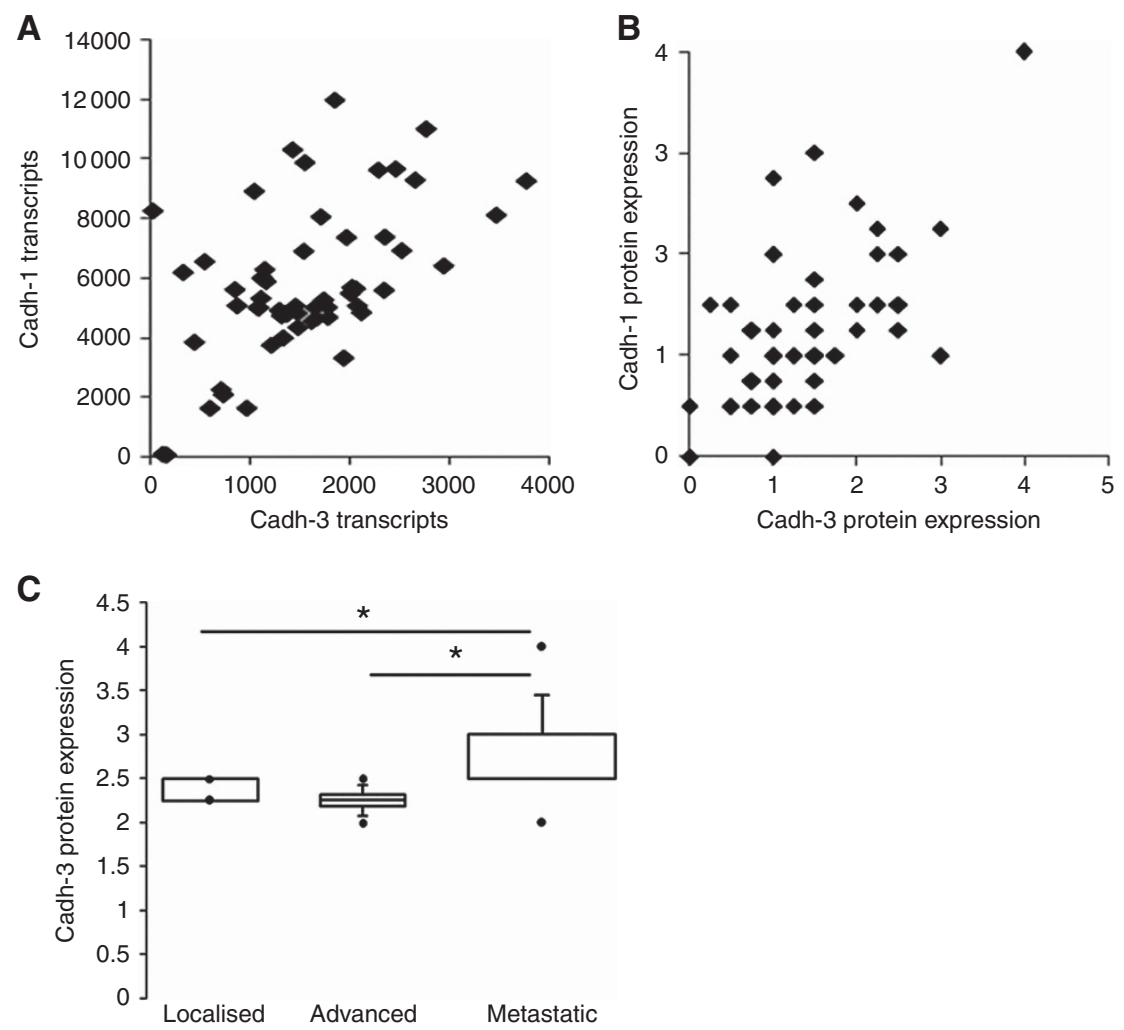

Figure 2. Cadherin-1 and -3 expressions in PDAC samples from xenografted tumours. (A) Both cadherins were quantified at the transcriptional level by using gene expression microarrays from xenografted tumours from 55 patients. (B) Cadherin-1 and cadherin-3 were immunodetected on a tissue array containing PDAC samples from xenografted tumours. Cadherin staining was scored as described in Materials and Methods. (C) Box plot represents cadherin-3 protein expression in PDAC samples from xenografted tumours issued primary tumours or from metastasis. ${ }^{\star} P<0.05$.

Cadherin-1 and cadherin-3 differentially regulate both invasion and cell migration. We next investigated the effect of cadherins on the cell-cell adhesion properties. BxPC-3 cadh- $1^{+} / \mathrm{cadh}-3^{+}$ cells and CRCM110-cadh- $1^{+} /$cadh- $3^{+}$cells spontaneously formed compact spheroids when cultured in suspension (Figure 4A), whereas spheroids formed by BxPC-3-cadh- $1^{-} /$cadh $^{-} 3^{+}$cells or CRCM08-cadh- $1^{-} /$cadh- $^{+}$cells were less compact. Quantification of the spheroids areas showed that cadherin-3-depleted spheroids were weakly increased compared with BxPC-3-cadh- $1^{+}$/ cadh- $3^{+}$spheroids. These results indicate that cadherin- 1 is the major player in cell-cell adhesion, although cadherin-3 regulates this essential biological phenomenon to a small extent.

The invasive capacity of human pancreatic cell lines expressing either both or one of the cadherins of interest was then analysed. BxPC-3-cadh- $1^{+} /$cadh- $3^{+}$cells organised in spheroids invaded a three-dimensional type I collagen gel (Figure 4B). Videomicroscopy experiments showed that this kind of invasion mainly required cell-cell contacts (Supplementary Figure S4). Cadherin-1 or cadherin-3 silencing inhibited this intercellular contact dependent cell invasion. Since neither cadherin-1 nor cadherin-3 was able to modulate cell proliferation, we have concluded that the decrease in the invasive capacity of the spheroids was not due to the cell proliferation inhibition (data not shown). Similar results were obtained with a type I collagen $2 \mathrm{D}$ invasion, an assay that did not require cell-cell contacts (Figure 4C). Interestingly, CRCM110 cells were more invasive than CRCM08 cells that express only cadherin-3. All in all, our data indicate that both cadherin-1 and cadherin-3 take part in intercellular-dependent and -independent invasion through type I collagen.

Cell invasion is a complex and multifactorial process that requires cell adhesion, extracellular matrix proteolysis and cell migration. We therefore set out to dissect the role of each cadherin during these crucial events. Collective cell migration (i.e., cell-cell contact dependent cell migration) was assessed by wound healing assay. While BxPC- 3 -cadh- $1^{+} /$cadh- $3^{+}$cells resulted in $30 \%$ of closed wound at $6 \mathrm{~h}$, there was a significant increase of cell migration for BxPC- 3 -cadh- $1^{-} / \mathrm{cadh}^{-} 3^{+}$cells (Figure 5A). Collective migration properties of cells expressing both cadherin- 1 and cadherin- 3 or only cadherin- 1 were quite similar. These findings suggest that collective migration of $\mathrm{BxPC}-3$ cells is enhanced by cadherin-3. We next analysed single cell migration by using timelapse microscopy. Cell tracking analysis indicated that cadherin-3 expression increased cell speed, but did not impair cell velocity and cell directionality (Figure 5B).

To determine whether cadherins drive invasive structures formations called invadopodia, cells were plated on FITC-labelled gelatin and gelatinolytic activity was detected by loss of FITCfluorescence. Cadherin-1, but not cadherin-3 depletion, promoted a reduction of the number of degradation areas formed at the ventral surface of cancer cells (Figure 5C and Supplementary Figure S5). Moreover, invadopodia were more abundant in CRCM110 cells compared to CRCM08 cells. These results strongly suggest that cadherin-1 regulates invadopodia formation.

Cadherin-1 and cadherin-3 differentially regulate tumour microenvironment. To assess the differential effect of cadherins on the primary tumour development, the different BxPC-3 cell lines were subcutaneously implanted into the flank of nude mice. Twenty-one days following cell injections, we analysed tumour growth which was expressed as the product of perpendicular diameters. As shown in Figure 6A, cadherin-3 depletion induced the tumour growth delay. However, cadherin-1 expression did not slow down tumoural growth. The measurement of tumour weights confirmed these observations, as shown in Figure 6A. Since 

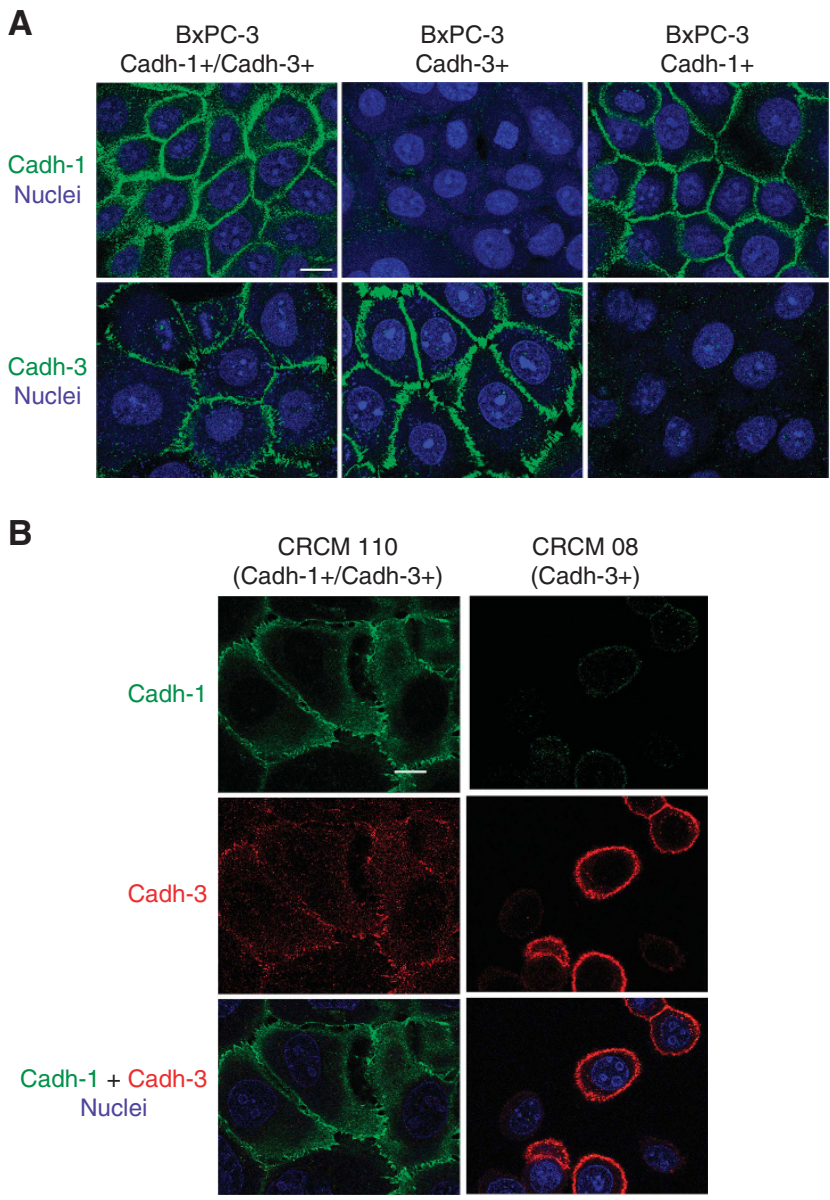

Figure 3. Cadherin expression in BxPC-3 cell models and in primary cultures from human tumours. (A) Cadherin-1 or cadherin-3 expression was invalidated in BxPC-3 human pancreatic cancer cell line.

Generated stable cell lines were called BxPC-3-cadh- $1^{+} /$cadh- $3^{+}$(no cadherin depletion), BxPC-3-cadh-1 ${ }^{+}$(cadherin-3 depletion) and BxPC3 -cadh- $3^{+}$(cadherin-1 depletion). Cadherin-1 and cadherin-3 expression was assessed by immunofluorescence. Scale bar: $15 \mu \mathrm{m}$. (B) Cadherin-1 and cadherin-3 were sequentially immunostained in CRCM110 and CRCM08 primary cell cultures derived from human tumours. Scale bar: $15 \mu \mathrm{m}$.

pancreatic tumours are largely composed of stroma with type I collagen as the major component, we therefore analysed the impact of cadherin expression on the stroma organisation. Masson's trichrome staining demonstrated a extracellular matrix proteins fibres deposit in tumours formed by BxPC-3-cadh- $1^{+} / \mathrm{cadh}^{-} 3^{+}$, BxPC-3 cadh $-1^{+} /$cadh $^{-} 3^{-}$, and CRCM110 (Figure 6B). However, the presence of extracellular matrix proteins fibres was strongly reduced in cells that do not express cadherin-1. We then immunostained type I collagen. As observed on Supplementary Figure S6, type I collagen represents the main compound of the extracellular matrix proteins fibres stained by Masson's trichrome. Overall, our data suggest that cadherin-1 expressing malignant cells are able to drive type I collagen organisation in the tumour.

To confirm these observations, cells were orthotopically implanted into the pancreas of nude mice. Three weeks after the implantation, pancreas weights were measured to evaluate tumoural growth. The data shown in Figure 7A confirm the role of cadherin-3 in tumour development (Figure 7A). We next investigated the morphology of the tumours by using a Masson's trichrome staining (Figure 7B). Regardless of the cell lines implanted, orthotopic tumours were separated from the mouse pancreatic tissue by a layer of type I collagen fibres. However, orthotopic tumours formed by BxPC-3-cadh- $1^{-} /$cadh- $3^{+}$cells showed much less collagen fibres than those formed by cadherin-1expressing cells (Figure 7C). Altogether, our results confirm that cadherin-1 expression in malignant cells regulates type I collagen organisation in the tumour.

Taken together these results indicate that cadherin-1 and cadherin-3 differentially regulate PDAC aggressiveness.

\section{DISCUSSION}

According to our findings, the role of both cadherin-1 and cadherin-3 in PDAC progression can be summarised as follows: (1) cadherin-3 is progressively expressed at the plasma membrane during progression of PanIN-1 to PDAC. Despite a decrease in cadherin-1 levels, significant amounts remained associated with the cell surface; (2) cadherin-1 localises with cadherin-3 in pancreatic cancer cells suggesting that these two adhesion molecules could elaborate adhesive networks. The latter may regulate pancreatic cancer cell behaviour; (3) both cadherin-1 and cadherin-3 are involved in the cancer cell invasion through distinct processes: cadherin- 3 regulates cell migration, whereas cadherin- 1 takes part in the invadopodia activity; (4) cadherin-3 regulates tumour growth. However, when associated with cadherin-3, cadherin-1 expression does not slow down tumoural growth; (5) cadherin-1 drives type I collagen fibres organisation in the tumour.

Several previous studies have shown that cadherin-3 upregulation is associated with aggressive pancreatic tumour behaviour (Taniuchi et al, 2005; Imai et al, 2008; Sakamoto et al, 2015). However, its detection at the early stages of pancreatic cancer development has not been studied. Here, we demonstrated that cadherin-3 seems to be upregulated at an early stage of PDAC. Indeed, by using a human tissue microarray and a mouse model that develops PanIN lesions similar to human (PDX1-Cre, $\mathrm{Kras}^{\mathrm{G} 12 \mathrm{D}}$, Ink4a/Arf ${ }^{\text {lox/flox }}$ ), we have shown that cadherin-3 is detected at the cell membrane since PanIN-1 development. Moreover, cadherin-3 expression increased at the cell membrane during progression from PanIN to PDAC and was maximal in metastatic pancreatic cancers. This early cadherin- 3 expression is not unique to pancreatic cancer, since an aberrant cadherin-3 expression was also described from the earliest morphologically identifiable stage of colon and breast cells transformation (Vieira and Paredes, 2015). Our results have shown that cadherin-3 is expressed early during the time course of PDAC. Since its expression is associated with poor prognosis in patients (Sakamoto et al, 2015), it is tempting to speculate that cadherin3 could be used as a diagnostic marker for PDAC. This adhesion molecule therefore represents a promising molecular target in the development of a novel anticancer therapy. It would be essential to test the impact of cadherin-3 antagonising molecules during progression from PanIN to PDAC in order to design effective therapies for patients with this lethal disease.

In several types of cancers, cadherins undergo cleavages from cell membrane by ectodomain shedding (De Wever et al, 2007; Ribeiro et al, 2010). The releasing soluble cadherin (s-cad) may still have functional activity as paracrine/autocrine competitor of cadherin function. Significantly elevated s-cad levels, including s-cadherin-1, s-cadherin-2 and s-cadherin-3, have been observed in the sera and urine of cancer patients diagnosed with a variety of cancers. Moreover, in several types of cancers, increased circulating levels of s-cad are indicative of histopathological grade, metastasis recurrence and poor prognosis (Ribeiro et al, 2010). Further studies are required to determine whether circulating s-cadherin-3 is a potential biomarker for pancreatic cancer. According to this, s-cadherin-3 was identified in proteomic analysis of secretomes 

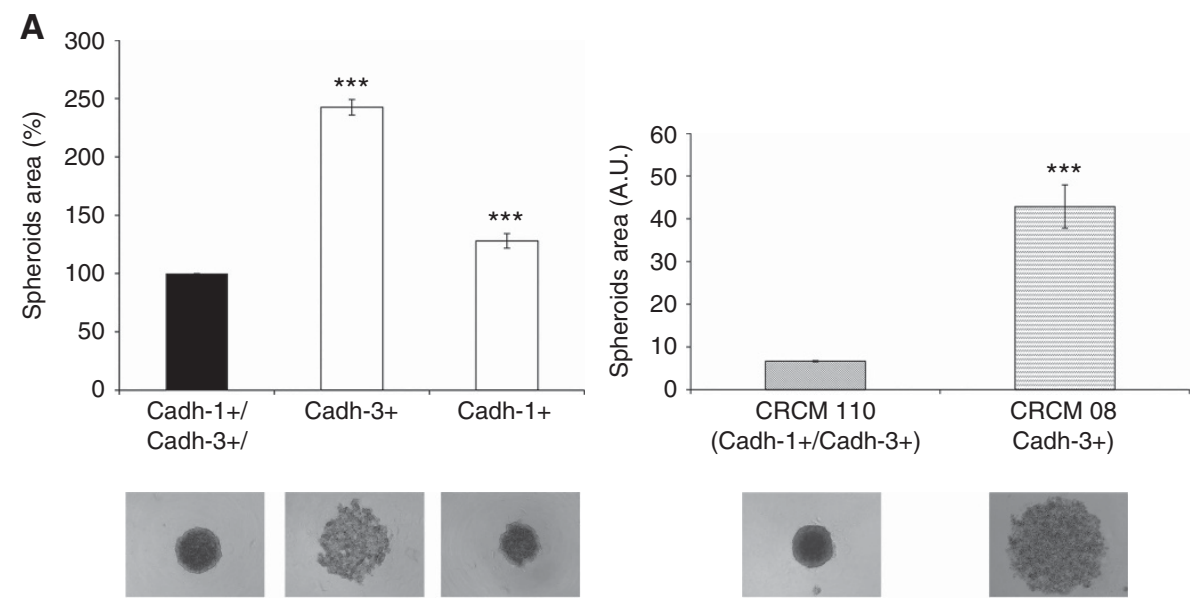

B
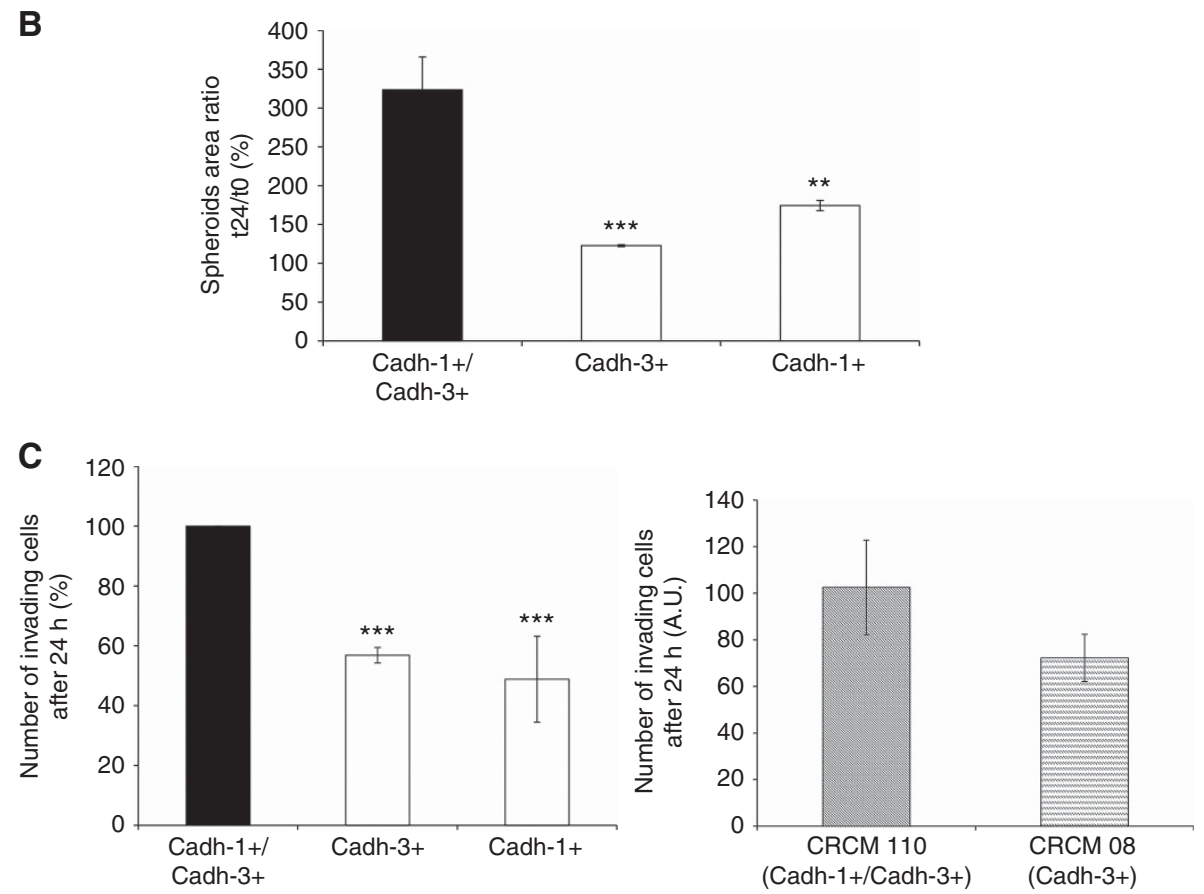

Figure 4. Both cadherin-1 and cadherin-3 regulate cancer cell invasion. (A) The impact of cadherins expression on cell-cell adhesion properties was assessed by a spheroid formation assay. BxPC-3-cadh-1+/cadh-3+ (no cadherin depletion), BxPC-3-cadh1 ${ }^{+}$(cadherin-3 depletion) BxPC-3cadh $-3^{+}$(cadherin-1 depletion) cells, as well as primary cultures from human tumours CRCM110 and CRCM08 were allowed to form spheroids in suspension for $24 \mathrm{~h}$. The spheroid area was measured by phase contrast microscopy and analysed by ImageJ. Data represent the mean \pm s.d. of three separate experiments performed in triplicates. (B) BxPC-3 cell models were allowed to form spheroids for $72 \mathrm{~h}$. Spheroids were then embedded in type I collagen. After the embedding followed by a $24 \mathrm{~h}$ incubation period, the spheroid area was measured by phase contrast microscopy and analysed by ImageJ. Data represent the mean \pm s.d. of three independent experiments performed in triplicates. (C) Isolated BxPC3 cells and primary cultures from human tumours CRCM110 and CRCM08 were allowed to invade a layer of type I collagen for $24 \mathrm{~h}$. The invasion index was calculated as the mean number of migrated cells counted in 10 microscopic fields. Data represent the mean \pm s.d. of three independent experiments performed in triplicates. ${ }^{\star \star} P<0.01,{ }^{\star \star \star} P<0.001$.

from PDAC samples from 55 patients preserved as xenografts in nude mice (our preliminary results).

The role of cadherin-3 in tumour cell invasion is subject to tumour type and cell context (tissue architecture and microenvironment). There are controversial reports regarding the invasive role of cadherin-3 in different cancer models. Although some studies demonstrated an anti-invasive function of cadherin-3 in melanoma, colon cancer and hepatocarcinoma (Van Marck et al, 2005, 2011; Bauer et al, 2014); other studies have revealed proinvasive function in bladder, breast, ovarian, intra-hepathic collangioma and pancreatic cancer (Paredes et al, 2004; Taniuchi et al, 2005; Cheung et al, 2010; Van Marck et al, 2011; Sakamoto et al, 2015). In the current study, we showed that cadherin-3 downregulation partially reduced tumour growth in mice. Moreover, cadherin-3 depletion significantly decreased cancer cell invasion through type I collagen in 2D (cell-cell contacts independent) and 3D (cell-cell contacts dependent) invasion assays. The latter appears more physiologically relevant, since instead of using matrigel, we have chosen to work with type I collagen, the major component of the PDAC stroma (Sakamoto et al, 2015). Furthermore, we showed that cadherin-3 is responsible of collective cancer cell migration. According to this, cadherin-3 overexpression in cadherin-3-deficient pancreatic cancer cells induced an increase of cell migration (Taniuchi et al, 2005). It was recently shown that cadherin-3 expression in mesenchymal myoblasts regulates planar cell polarisation and collective cell 
A
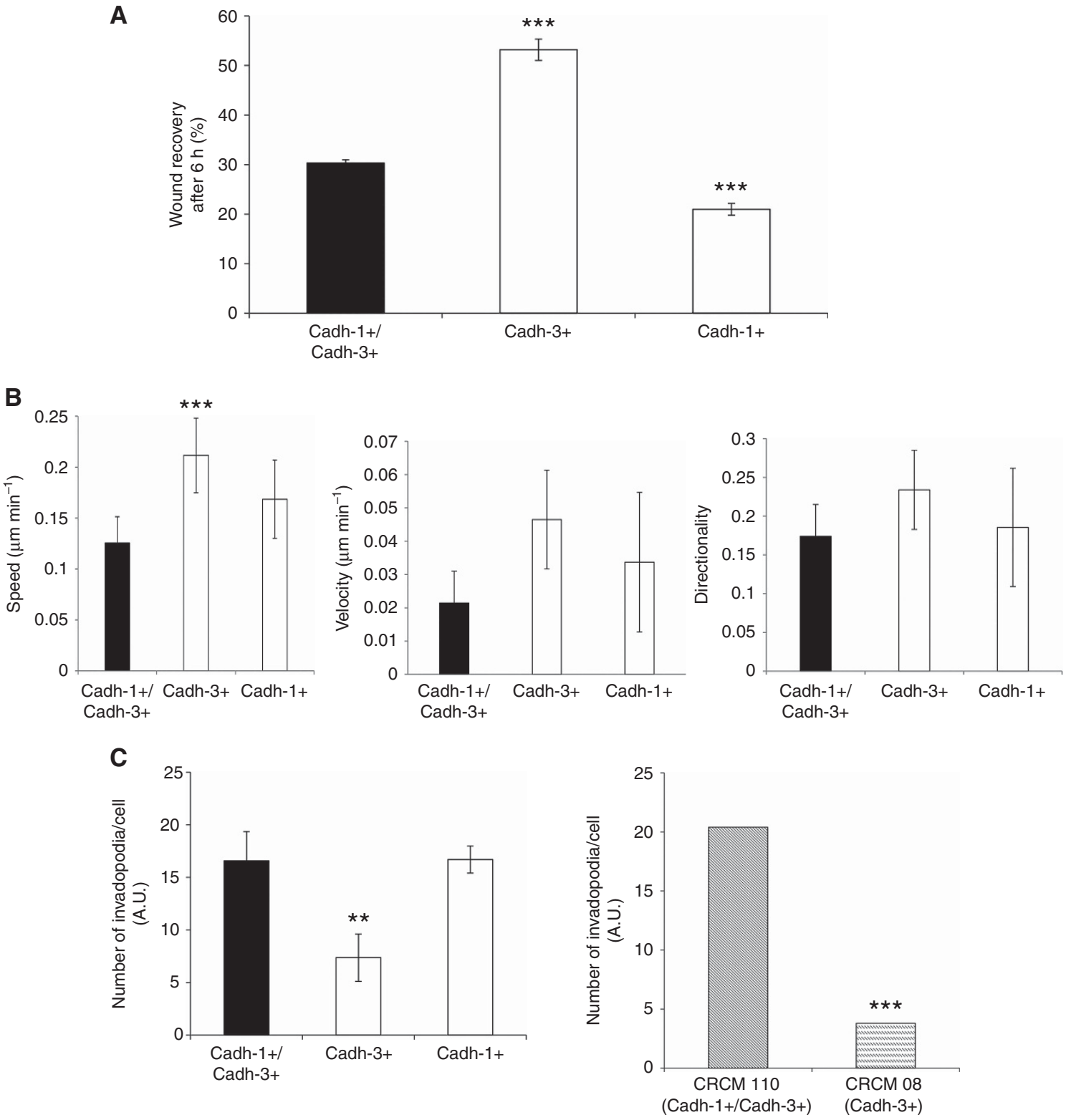

Figure 5. Cadherin-3 drives migration of pancreatic tumour cells, whereas cadherin-1 is involved in invadopodia formation. (A) BxPC-3 cell monolayers were wounded and incubated in culture medium. Results are expressed as the percentage of wound area closure which was determined after $6 \mathrm{~h}$ of incubation. Data represent the mean \pm s.d. of three independent experiments performed in triplicates. (B) Isolated BxPC-3 cells were plated onto type I collagen. For $6 \mathrm{~h}$ the single cell trajectories were analysed by videomicroscopy by capturing images every 5 min. Different parameters such as the speed, the velocity and the directionality were analysed from the cell tracks obtained using ImageJ software. (C) Isolated BxPC-3 cells and primary cultures from human tumours were plated for $16 \mathrm{~h}$ on FITC-conjugated gelatin. The areas of degraded matrix were observed with confocal microscope. ImageJ software was used to evaluate the number of invadopodia per cell. Data represent the mean \pm s.d. of three independent experiments performed in triplicates. ${ }^{\star \star} P<0.01,{ }^{\star \star *} P<0.001$.

migration (Plutoni et al, 2016). Altogether, these data confirm that cadherin-3 overexpression in PDAC is associated with the invasive phenotype and malignant behaviour.

It is well established that cadherin-1 plays an important role as an invasion suppressor (Rodriguez et al, 2012). However, recent studies suggested that this molecule may also have a promoting role in ovarian, breast and glioma cancer progression (Rodriguez et al, 2012). Nonetheless, much remains to be learned about its role in tumour progression. In the present study, we have demonstrated that cadherin-1 participates to PDAC progression. Indeed, by using $\mathrm{BxPC}-3$ cell models and primary culture from human tumours, we showed that cadherin-1 (1) regulates cell invasion through type $\mathrm{I}$ collagen $3 \mathrm{D}$ and $2 \mathrm{D}$ invasion assays; (2) increases motility of isolated cells; (3) does not affect tumour growth in mice.

It is now clear that a switching from cadherin-1 to cadherin-2 and/or cadherin-3 is a hallmark of epithelial-mesenchymal transition (EMT) in several types of cancer including prostate, ovarian and bladder cancers. By using double immunostaining experiments on human and murine tissue specimens, we have shown that cells co-expressed at their surface both cadherin-1 and cadherin-3 from early PanIN lesions to PDAC. These data indicate that in PDAC cadherin switching refers to a situation in which cadherin-1 levels do not change significantly, but cells turn on cadherin-3 expression. Moreover, the co-expression of cadherin-1 and cadherin-2 was also described in a mouse model of K-ras- 
A
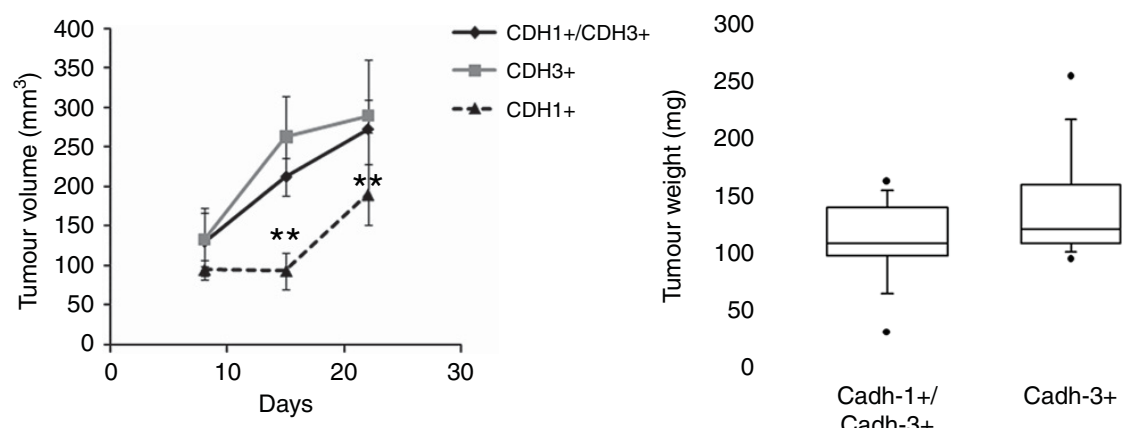

Cadh-1+/

Cadh-3+

B

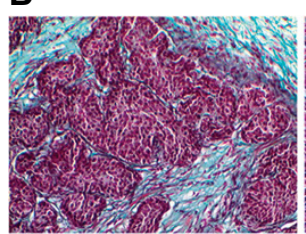

Cadh-1+/Cadh-3+

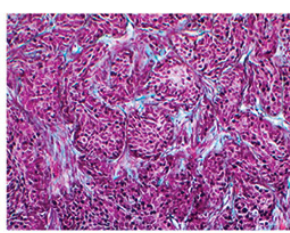

Cadh-3+

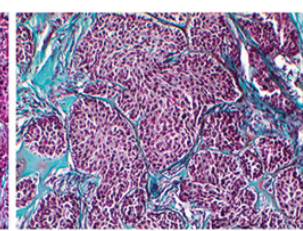

Cadh-1+
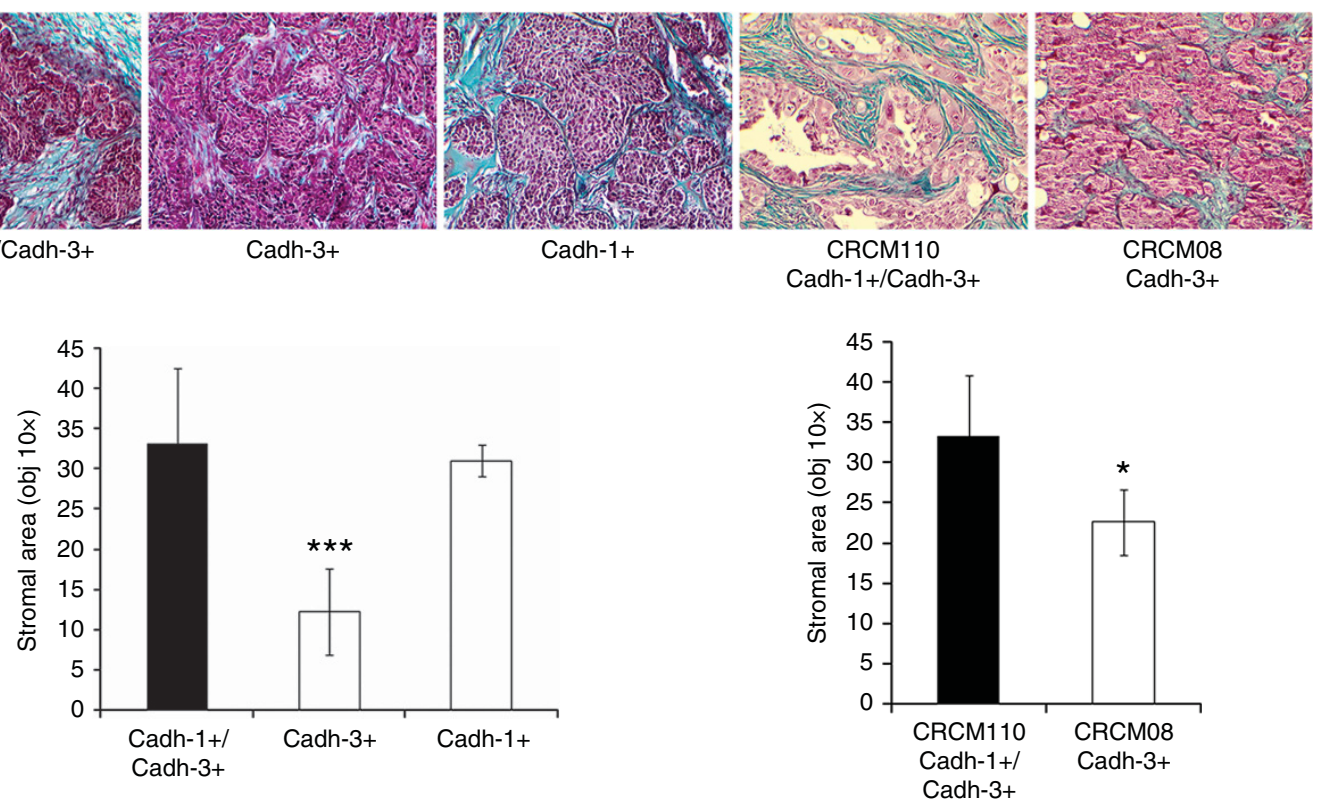

Figure 6. Effects of cadherin-1 and cadherin-3 silencing on tumour growth and ECM deposition. (A) Different BxPC 3 cells lines were injected into the flank of nude mice. For 21 days, mice were monitored weekly for tumour growth ( $n=6$ for each condition). Box plot represents tumour weight 3 weeks after cell inoculation. (B) Tumours were fixed, embedded in paraffin, cut into $4 \mu \mathrm{m}$ sections, and submitted to Masson's trichrome staining to distinguish collagen (in blue) from other tissue structures. The stromal area of each tumour was measured by microscopy ( $\times 10$ objective) and analysed by ImageJ. ${ }^{*} P<0.05,{ }^{\star *} P<0.01,{ }^{\star \star *} P<0.001$.

induced PanIN (Su et al, 2016). Taken together these findings suggest that cadherin switching in PDAC is not required for the EMT process.

Herein, we have observed that simultaneous expression of cadherin- 1 and cadherin-3 is the most frequent situation in PDAC. Indeed, double immunostaining analysis on a human tissue microarray revealed that these adhesion molecules are jointly expressed at the cell surface of tumoural cells in a large proportion of PDAC (41\%). These results were confirmed by using gene transcription and protein expression analysis on 55 samples of PDAC from patient preserved as xenografts in nude mice. According to this, same simultaneous expression of cadherins was described in a quarter of breast carcinomas (Ribeiro et al, 2013). Based on these data, we propose that the co-expression of cadherin- 1 and cadherin- 3 could be a signature of an increased invasive and tumourigenic potential in PDAC.

PDAC is characterised by a dense desmoplastic stroma with type I collagen as the major component (Feig et al, 2012). However, the process of driving collagen deposition and organisation in PDAC remains unknown. Our results suggest that different type I collagen organisation could be generated depending on the type of cadherin expressed by tumoural cells. Indeed, orthotopic and ectopic injection of BxPC-3 cells in nude mice revealed that malignant cells expressing cadherin-1 drive type I collagen deposition. Moreover, Masson's trichrome staining of PDAC samples from xenografted tumours of patients confirmed that cadherin-1-positive cells promoted a strong collagen deposition. Therefore, rather than collagen abundance, the architecture and mechanics of collagen fibres adjacent to epithelial lesion may be an indicator of PDAC progression (Laklai et al, 2016). Further studies are required to determine whether the nature of the cadherin(s) expressed by tumour cells alters the organisation of collagen bundles.

Extracellular matrix is a key physical barrier to cancer cell invasion. It is now well known that focal extracellular matrix degradation and remodelling are required to open space and create tracks along which metastatic tumour cells can migrate through tissue. Invadopodia, specialised proteolytically active plasma membrane protrusions, are crucial for this mechanism (Gimona et al, 2008). Extracellular matrix proteolysis mediated by invadopodia is mainly executed by matrix-degrading proteases including membrane type-1 matrix metaloproteinase (MT1MMP), as well as by matrix metalloproteinase-2 (MMP-2) and 9 (MMP-9) (Castro-Castro et al, 2016). These proteases are overexpressed in metastatic PDAC lesions compared with primary tumours (Ottaviano et al, 2006; Jakubowska et al, 2016). Our 
A

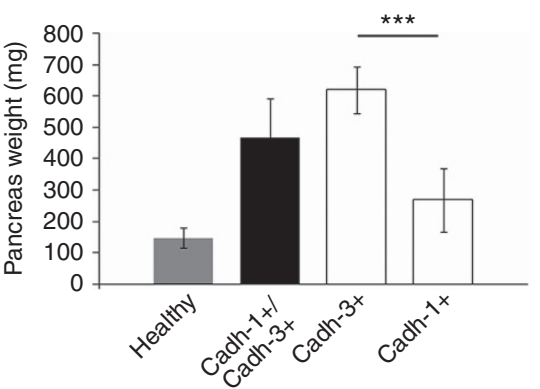

B

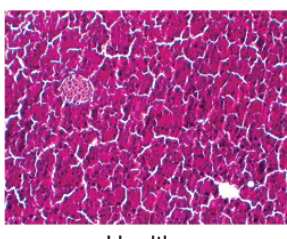

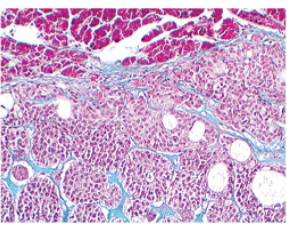

Cadh-1+/Cadh-3+

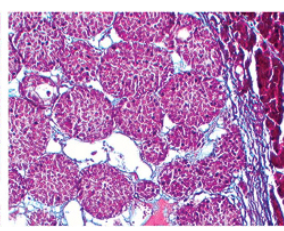

Cadh-3+

C

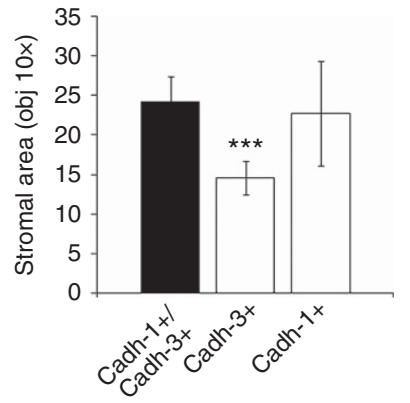

Figure 7. Cadherins alter ECM deposition. Mice were orthotopically implanted with either BxPC-3-cadh- $1^{+} / \mathrm{cadh}-3+, \mathrm{BxPC}-3-\mathrm{cadh} 1{ }^{+}$or BxPC3 -cadh- $3^{+}$cells resuspended in Matrigel or with Matrigel alone ( $n=3$ for each condition). (A) Mice were sacrificed 21 days after injection, pancreas were collected and the weight was measured. (B) Sections of graft tissue specimens were subjected to Masson's trichrome staining. (C) The stromal area of each tumour was measured by microscopy $\left(10 \times\right.$ objective) and analysed by ImageJ. ${ }^{\star \star \star} P<0.001$.

studies revealed that pancreatic cancer cell line $\mathrm{BxPC}-3$ and primary culture from human tumours are able to develop invadopodia to degrade extracellular matrix. Indeed in this assay cadherin-1-deficient cells (BxPC-3-cadh- ${ }^{-} /$cadh $^{+} 3^{+}$and CRCM08-cadh- $1^{-} / \mathrm{cadh}^{-} 3^{+}$) have a reduced focal gelatinolytic activity. We have therefore concluded that the formation of invadopodia involves cadherin-1 expression. The mechanism by which cadherin-1 drives invadopodia formation remains unknown, but needs to be further elucidated. Indeed, clarifying how cadherin-1 signalling regulates extracellular matrix degradation should improve our understanding of invadopodia lifecycle in order to target them and prevent cancer cell invasion and metastasis.

In summary, our data demonstrate that pro-tumoural signalling environments can be generated according to the type of cadherin expressed by cancer cells, which can lead to differential cell responses including invasion, migration or regulation of extracellular matrix deposition and degradation. Importantly, these findings open new avenues towards uncovering innovative options for earlier diagnosis and anti-invasive therapy of pancreatic cancer.

\section{ACKNOWLEDGEMENTS}

This work was supported by grant in aid $\mathrm{Nb} 6038$ from INCa, Inserm and DGOS (SIRIC label).

\section{CONFLICT OF INTEREST}

The authors declare no conflict of interest.

\section{REFERENCES}

Al-Aynati MM, Radulovich N, Riddell RH, Tsao MS (2004) Epithelialcadherin and beta-catenin expression changes in pancreatic intraepithelial neoplasia. Clin Cancer Res 10(4): 1235-1240.

Bailey P, Chang DK, Nones K, Johns AL, Patch AM, Gingras MC, Miller DK, Christ AN, Bruxner TJ, Quinn MC, Nourse C, Murtaugh LC, Harliwong I, Idrisoglu S, Manning S, Nourbakhsh E, Wani S, Fink L, Holmes O, Chin V, Anderson MJ, Kazakoff S, Leonard C, Newell F, Waddell N, Wood S, Xu Q, Wilson PJ, Cloonan N, Kassahn KS, Taylor D, Quek K, Robertson A, Pantano L, Mincarelli L, Sanchez LN, Evers L, Wu J, Pinese M, Cowley MJ, Jones MD, Colvin EK, Nagrial AM, Humphrey ES, Chantrill LA, Mawson A, Humphris J, Chou A, Pajic M, Scarlett CJ, Pinho AV, Giry-Laterriere M, Rooman I, Samra JS, Kench JG, Lovell JA, Merrett ND, Toon CW, Epari K, Nguyen NQ, Barbour A, Zeps N, Moran-Jones K, Jamieson NB, Graham JS, Duthie F, Oien K, Hair J, Grützmann R, Maitra A, Iacobuzio-Donahue CA, Wolfgang CL, Morgan RA, Lawlor RT, Corbo V, Bassi C, Rusev B, Capelli P, Salvia R, Tortora G, Mukhopadhyay D, Petersen GM, Munzy DM, Fisher WE, Karim SA, Eshleman JR, Hruban RH, Pilarsky C, Morton JP, Sansom OJ, Scarpa A, Musgrove EA, Bailey UM, Hofmann O, Sutherland RL, Wheeler DA, Gill AJ, Gibbs RA, Pearson JV, Biankin AV, Grimmond SM, Initiative APCG (2016) Genomic analyses identify molecular subtypes of pancreatic cancer. Nature 531(7592): 47-52. 
Bauer R, Valletta D, Bauer K, Thasler WE, Hartmann A, Müller M, Reichert TE, Hellerbrand C (2014) Downregulation of P-cadherin expression in hepatocellular carcinoma induces tumourigenicity. Int $\mathrm{J}$ Clin Exp Pathol 7(9): 6125-6132.

Castro-Castro A, Marchesin V, Monteiro P, Lodillinsky C, Rossé C, Chavrier P (2016) Cellular and molecular mechanisms of MT1-MMPdependent cancer cell invasion. Annu Rev Cell Dev Biol 32: 555-576.

Chai MG, Kim-Fuchs C, Angst E, Sloan EK (2013) Bioluminescent orthotopic model of pancreatic cancer progression. J Vis $\operatorname{Exp}$ (76).

Cheung LW, Leung PC, Wong AS (2010) Cadherin switching and activation of p120 catenin signaling are mediators of gonadotropin-releasing hormone to promote tumor cell migration and invasion in ovarian cancer. Oncogene 29(16): 2427-2440.

De Wever O, Derycke L, Hendrix A, De Meerleer G, Godeau F, Depypere H, Bracke M (2007) Soluble cadherins as cancer biomarkers. Clin Exp Metastasis 24(8): 685-697.

Duconseil P, Gilabert M, Gayet O, Loncle C, Moutardier V, Turrini O, Calvo E, Ewald J, Giovannini M, Gasmi M, Bories E, Barthet M, Ouaissi M, Goncalves A, Poizat F, Raoul JL, Secq V, Garcia S, Viens P, Iovanna J, Dusetti N (2015) Transcriptomic analysis predicts survival and sensitivity to anticancer drugs of patients with a pancreatic adenocarcinoma. Am J Pathol 185(4): 1022-1032.

Fabre C, el Battari A, Bellan C, Pasqualini E, Marvaldi J, Lombardo D, Luis J (1993) Characterization of the oligosaccharide moiety of VIP receptor from the human pancreatic cell line BxPC-3. Peptides 14(6): 1331-1338.

Feig C, Gopinathan A, Neesse A, Chan DS, Cook N, Tuveson DA (2012) The pancreas cancer microenvironment. Clin Cancer Res 18(16): 4266-4276.

Gayet O, Loncle C, Duconseil P, Gilabert M, Lopez MB, Moutardier V, Turrini O, Calvo E, Ewald J, Giovannini M, Gasmi M, Bories E, Barthet M, Ouaissi M, Goncalves A, Poizat F, Raoul JL, Secq V, Garcia S, Viens P, Dusetti N, Iovanna J (2015) A subgroup of pancreatic adenocarcinoma is sensitive to the 5-aza-dC DNA methyltransferase inhibitor. Oncotarget 6(2): 746-754.

Gimona M, Buccione R, Courtneidge SA, Linder S (2008) Assembly and biological role of podosomes and invadopodia. Curr Opin Cell Biol 20(2): 235-241.

Gul IS, Hulpiau P, Saeys Y, van Roy F (2017) Evolution and diversity of cadherins and catenins. Exp Cell Res 358(1): 3-9.

Hruban RH, Maitra A, Schulick R, Laheru D, Herman J, Kern SE, Goggins M (2008) Emerging molecular biology of pancreatic cancer. Gastrointest Cancer Res 2(4 Suppl): S10-S15.

Imai K, Hirata S, Irie A, Senju S, Ikuta Y, Yokomine K, Harao M, Inoue M, Tsunoda T, Nakatsuru S, Nakagawa H, Nakamura Y, Baba H, Nishimura Y (2008) Identification of a novel tumor-associated antigen, cadherin 3/P-cadherin, as a possible target for immunotherapy of pancreatic, gastric, and colorectal cancers. Clin Cancer Res 14(20): 6487-6495.

Jakubowska K, Pryczynicz A, Januszewska J, Sidorkiewicz I, Kemona A, Niewiński A, Lewczuk Ł, Kędra B, Guzińska-Ustymowicz K (2016) Expressions of matrix metalloproteinases 2, 7, and 9 in carcinogenesis of pancreatic ductal adenocarcinoma. Dis Markers 2016: 9895721.

Karandish F, Mallik S (2016) Biomarkers and Targeted Therapy in Pancreatic Cancer. Biomark Cancer 8(Suppl 1): 27-35.

Kim MP, Evans DB, Wang H, Abbruzzese JL, Fleming JB, Gallick GE (2009) Generation of orthotopic and heterotopic human pancreatic cancer xenografts in immunodeficient mice. Nat Protoc 4(11): 1670-1680.

Kleeff J, Korc M, Apte M, La Vecchia C, Johnson CD, Biankin AV, Neale RE, Tempero M, Tuveson DA, Hruban RH, Neoptolemos JP (2016) Pancreatic cancer. Nat Rev Dis Primers 2: 16022.

Laklai H, Miroshnikova YA, Pickup MW, Collisson EA, Kim GE, Barrett AS, Hill RC, Lakins JN, Schlaepfer DD, Mouw JK, LeBleu VS, Roy N, Novitskiy SV, Johansen JS, Poli V, Kalluri R, Iacobuzio-Donahue CA, Wood LD, Hebrok M, Hansen K, Moses HL, Weaver VM (2016) Genotype tunes pancreatic ductal adenocarcinoma tissue tension to induce matricellular fibrosis and tumor progression. Nat Med 22(5): 497-505.

Leca J, Martinez S, Lac S, Nigri J, Secq V, Rubis M, Bressy C, Sergé A, Lavaut MN, Dusetti N, Loncle C, Roques J, Pietrasz D, Bousquet C, Garcia S, Granjeaud S, Ouaissi M, Bachet JB, Brun C, Iovanna JL, Zimmermann P, Vasseur S, Tomasini R (2016) Cancer-associated fibroblast-derived annexin A6 + extracellular vesicles support pancreatic cancer aggressiveness. J Clin Invest 126(11): 4140-4156.

Nakajima S, Doi R, Toyoda E, Tsuji S, Wada M, Koizumi M, Tulachan SS, Ito D, Kami K, Mori T, Kawaguchi Y, Fujimoto K, Hosotani R, Imamura M (2004) N-cadherin expression and epithelial-mesenchymal transition in pancreatic carcinoma. Clin Cancer Res 10(12 Pt 1): 4125-4133.
Nelson WJ (2008) Regulation of cell-cell adhesion by the cadherin-catenin complex. Biochem Soc Trans 36(Pt 2): 149-155.

Niessen CM, Leckband D, Yap AS (2011) Tissue organization by cadherin adhesion molecules: dynamic molecular and cellular mechanisms of morphogenetic regulation. Physiol Rev 91(2): 691-731.

Ottaviano AJ, Sun L, Ananthanarayanan V, Munshi HG (2006) Extracellular matrix-mediated membrane-type 1 matrix metalloproteinase expression in pancreatic ductal cells is regulated by transforming growth factor-betal. Cancer Res 66(14): 7032-7040.

Paredes J, Stove C, Stove V, Milanezi F, Van Marck V, Derycke L, Mareel M, Bracke M, Schmitt F (2004) P-cadherin is up-regulated by the antiestrogen ICI 182,780 and promotes invasion of human breast cancer cells. Cancer Res 64(22): 8309-8317.

Plutoni C, Bazellieres E, Le Borgne-Rochet M, Comunale F, Brugues A, Séveno M, Planchon D, Thuault S, Morin N, Bodin S, Trepat X, Gauthier-Rouvière C (2016) P-cadherin promotes collective cell migration via a Cdc42mediated increase in mechanical forces. J Cell Biol 212(2): 199-217.

Rahib L, Smith BD, Aizenberg R, Rosenzweig AB, Fleshman JM, Matrisian LM (2014) Projecting cancer incidence and deaths to 2030: the unexpected burden of thyroid, liver, and pancreas cancers in the United States. Cancer Res 74(11): 2913-2921.

Ribeiro AS, Albergaria A, Sousa B, Correia AL, Bracke M, Seruca R, Schmitt FC, Paredes J (2010) Extracellular cleavage and shedding of P-cadherin: a mechanism underlying the invasive behaviour of breast cancer cells. Oncogene 29(3): 392-402.

Ribeiro AS, Paredes J (2014) P-cadherin linking breast cancer stem cells and invasion: a promising marker to identify an 'intermediate/metastable' EMT state. Front Oncol 4: 371.

Ribeiro AS, Sousa B, Carreto L, Mendes N, Nobre AR, Ricardo S, Albergaria A, Cameselle-Teijeiro JF, Gerhard R, Söderberg O, Seruca R, Santos MA, Schmitt F, Paredes J (2013) P-cadherin functional role is dependent on E-cadherin cellular context: a proof of concept using the breast cancer model. J Pathol 229(5): 705-718.

Rodriguez FJ, Lewis-Tuffin LJ, Anastasiadis PZ (2012) E-cadherin's dark side: possible role in tumor progression. Biochim Biophys Acta 1826(1): 23-31.

Sakamoto K, Imai K, Higashi T, Taki K, Nakagawa S, Okabe H, Nitta H, Hayashi H, Chikamoto A, Ishiko T, Beppu T, Baba H (2015) Significance of P-cadherin overexpression and possible mechanism of its regulation in intrahepatic cholangiocarcinoma and pancreatic cancer. Cancer Sci 106(9): $1153-1162$.

Singh M, Maitra A (2007) Precursor lesions of pancreatic cancer: molecular pathology and clinical implications. Pancreatology 7(1): 9-19.

Siret C, Terciolo C, Dobric A, Habib MC, Germain S, Bonnier R, Lombardo D, Rigot V, André F (2015) Interplay between cadherins and $\alpha 2 \beta 1$ integrin differentially regulates melanoma cell invasion. Br J Cancer 113(10): $1445-1453$

Steffen A, Le Dez G, Poincloux R, Recchi C, Nassoy P, Rottner K, Galli T, Chavrier P (2008) MT1-MMP-dependent invasion is regulated by TI-VAMP/VAMP7. Curr Biol 18(12): 926-931.

Su Y, Li J, Shi C, Hruban RH, Radice GL (2016) N-cadherin functions as a growth suppressor in a model of K-ras-induced PanIN. Oncogene 35(25): 3335-3341.

Taniuchi K, Nakagawa H, Hosokawa M, Nakamura T, Eguchi H, Ohigashi H, Ishikawa O, Katagiri T, Nakamura Y (2005) Overexpressed P-cadherin/ $\mathrm{CDH} 3$ promotes motility of pancreatic cancer cells by interacting with p120ctn and activating rho-family GTPases. Cancer Res 65(8): 3092-3099.

Terciolo C, Dobric A, Ouaissi M, Siret C, Breuzard G, Silvy F, Marchiori B, Germain S, Bonier R, Hama A, Owens R, Lombardo D, Rigot V, André F (2017) Saccharomyces boulardii CNCM I-745 restores intestinal barrier integrity by regulation of E-cadherin recycling. J Crohns Colitis 11(8): 999-1010.

Thiery JP (2009) [Epithelial-mesenchymal transitions in cancer onset and progression]. Bull Acad Natl Med 193(9): 1978-1979discussion 1978-9.

Van Marck V, Stove C, Jacobs K, Van den Eynden G, Bracke M (2011) $\mathrm{P}$-cadherin in adhesion and invasion: opposite roles in colon and bladder carcinoma. Int J Cancer 128(5): 1031-1044.

Van Marck V, Stove C, Van Den Bossche K, Stove V, Paredes J, Vander Haeghen Y, Bracke M (2005) P-cadherin promotes cell-cell adhesion and counteracts invasion in human melanoma. Cancer Res 65(19): 8774-8783.

Vieira AF, Paredes J (2015) P-cadherin and the journey to cancer metastasis. Mol Cancer 14: 178.

Waddell N, Pajic M, Patch AM, Chang DK, Kassahn KS, Bailey P, Johns AL, Miller D, Nones K, Quek K, Quinn MC, Robertson AJ, Fadlullah MZ, 
Bruxner TJ, Christ AN, Harliwong I, Idrisoglu S, Manning S, Nourse C, Nourbakhsh E, Wani S, Wilson PJ, Markham E, Cloonan N, Anderson MJ, Fink JL, Holmes O, Kazakoff SH, Leonard C, Newell F, Poudel B, Song S, Taylor D, Wood S, Xu Q, Wu J, Pinese M, Cowley MJ, Lee HC, Jones MD, Nagrial AM, Humphris J, Chantrill LA, Chin V, Steinmann AM, Mawson A, Humphrey ES, Colvin EK, Chou A, Scarlett CJ, Pinho AV, Giry-Laterriere M, Rooman I, Samra JS, Kench JG, Pettitt JA, Merrett ND, Toon C, Epari K, Nguyen NQ, Barbour A, Zeps N, Jamieson NB,

Graham JS, Niclou SP, Bjerkvig R, Grützmann R, Aust D, Hruban RH, Maitra A, Iacobuzio-Donahue CA, Wolfgang CL, Morgan RA, Lawlor RT, Corbo V, Bassi C, Falconi M, Zamboni G, Tortora G, Tempero MA,
Gill AJ, Eshleman JR, Pilarsky C, Scarpa A, Musgrove EA, Pearson JV, Biankin AV, Grimmond SM, Initiative APCG (2015) Whole genomes redefine the mutational landscape of pancreatic cancer. Nature 518(7540): 495-501.

This work is published under the standard license to publish agreement. After 12 months the work will become freely available and the license terms will switch to a Creative Commons AttributionNonCommercial-Share Alike 4.0 Unported License.

Supplementary Information accompanies this paper on British Journal of Cancer website (http://www.nature.com/bjc) 